\title{
Carbon Dioxide Emission Modeling of King Oyster Mushroom before and after Thinning Processes According to Temperature and Growth Stage
}

\author{
Dae Ho Jung ${ }^{1}$ and Jung Eek Son ${ }^{2,3}$ * \\ ${ }^{1}$ Assistant Professor, Department of Environmental Horticulture, Cheju Halla University, Jeju 63092, Korea \\ ${ }^{2}$ Professor, Department of Agriculture, Forest and Bioresources (Horticultural Science and Biotechnology), Seoul National \\ University, Seoul 08826, Korea \\ ${ }^{3}$ Adjunnct Professor, Research Institute of Agriculture and Life Sciences, Seoul National University, Seoul 08826, Korea
}

\begin{abstract}
Temperature and $\mathrm{CO}_{2}$ concentration affect the yield and quality of mushrooms. In particular, high $\mathrm{CO}_{2}$ concentration due to mushroom respiration induces specific physiological disorders of mushrooms. The objective of this study was to quantify the $\mathrm{CO}_{2}$ emission rate of King Oyster mushrooms (Pleurotus eryngii (DC.) Quél) as a function of temperature and growth stage during the cultivation including thinning processes. $\mathrm{CO}_{2}$ emission rates of the substrate including mycelium before and after thinning were significantly different. In the respiration model, the maintenance and $\mathrm{CO}_{2}$ production coefficients of fruit bodies were expressed as quadratic equations according to temperature. The total $\mathrm{CO}_{2}$ emission rate of a bottle of mushroom estimated by the model were validated with measured ones $\left(\mathrm{R}^{2}=0.71\right)$. The $\mathrm{CO}_{2}$ emission rates of the mushroom showed exponential and quadratical increases with growth stage and temperature at 16 to $25^{\circ} \mathrm{C}$, respectively. The $\mathrm{CO}_{2}$ emission rate models developed for King Oyster mushroom can be utilized to control the $\mathrm{CO}_{2}$ concentration and temperature in mushroom cultivation facilities.
\end{abstract}

Additional key words : Carbon dioxide, Fruit body, Respiration model, Substrate

\section{Introduction}

Commercial cultivation of mushrooms has sharply increased over the last few decades with the development of cultivation techniques. Among mushrooms such as Button mushroom, Shiitake mushroom, Oyster mushroom, Wood Ear mushroom, Straw mushroom, Enoki mushroom, and Snow Ear mushroom (Kües and Liu, 2000), Oyster mushrooms (Pleurotus genus) are widely cultivated in East Asia regions. The bottle cultivation methods developed since the 1950s have enabled large-scale production for commercial purposes (Kües and Liu, 2000; Yamanaka, 2011; Oh et al., 2017). However, because King Oyster mushrooms ( $P$. eryngii) are typically cultivated in bottles, environmental factors such as temperature, humidity, and $\mathrm{CO}_{2}$ concentration should be adequately controlled (Lee et al., 2003; Kim et al., 2019).

In mushroom cultivation, $\mathrm{CO}_{2}$ is emitted during mycelium incubation, initiation of fruit body, and its growth. The

*Corresponding author: sjeenv@snu.ac.kr

Received March 22, 2021; Revised April 20, 2021;

Accepted April 21, 2021 amount of emitted $\mathrm{CO}_{2}$ depends on strain species, weight, moisture content of the medium, incubation temperature, and incubation period (Jang et al., 2007). Mycelium growth and fruit body quality are negatively affected by accumulation of $\mathrm{CO}_{2}$. Indeed, Zadražil (1975) reported that the mycelium growth of Pleurotus mushrooms was suppressed when exposed to high $\mathrm{CO}_{2}$ concentrations of $22-28 \%$. In addition, the expansion of fruit body's pileus was inhibited at $\mathrm{CO}_{2}$ concentrations of 3,000-9,000 $\mu \mathrm{mol} \mathrm{CO}_{2} \cdot \mathrm{mol}^{-1}$ (Kinugawa et al., 1994), while the quality of the mushroom is optimal at 2,400 $\mu \mathrm{mol} \cdot \mathrm{mol}^{-1}$ (Ryu et al., 2005). To prevent physiological disorders during mycelium growth and fruit body formation, $\mathrm{CO}_{2}$ concentration level should be adequately controlled (Ryu et al., 2005; Jang et al., 2007; Jang et al., 2009). Quantitative analysis of mushroom $\mathrm{CO}_{2}$ emissions is thus very important, but it has been rarely performed during cultivating stage. When $\mathrm{O}_{2}$ concentration falls below 3\%, it was known that the opening of the mushroom pileus was prevented (Kamal et al., 2015). However, the $\mathrm{O}_{2}$ concentration is not an important factor because the $\mathrm{O}_{2}$ concentration is rarely lower than $3 \%$ in actual cultivation situations. 
Most of the recent studies for modelling the respiration of mushroom have been carried out for quality control after harvest (Azevedo et al., 2015), and Micaelis-Menten equations were mainly used (Iqbal et al., 2009). For modelling during crop growth, Thornley (1970) suggested a linear combination of net photosynthetic rate and plant dry weight. Likewise, a linear combination of dry weight and change rate of dry weight was applied to the mushroom. The respiration rate of each part of mushroom can be represented using dry weight models of the mycelium and fruit bodies (Chanter and Thornley, 1978). However, it is difficult to separate the medium from the mycelium in the middle of bottle cultivation conditions. Thus, in order to quantify the mushroom $\mathrm{CO}_{2}$ emission rate, it is necessary to determine the amount of mycelium in the substrate and use growth models reflecting growth characteristics of fruit bodies. In order to estimate the mycelium abundance, an image processing method utilizing photographs of medium crosssection was developed, in which the percentage change in mycelium as a function of temperature and humidity was expressed by a quadratic equation model (Yang et al., 2012). However, the conventional model described as above did not express how the respiration rate changes depending on temperatures in the substrate including mycelium and the fruit bodies during the cultivation of King Oyster mushroom.

Repeated harvests of fruit bodies from the medium may reduce the number and weight of fruit bodies (Flegg and Smith, 1982; Burton and Noble, 1993). For practical purposes, a method involving cutting the others except $1-2$ large fruit bodies, called thinning, is widely used to improve the quality of King Oyster mushroom cultivars (Ryu et al., 2005). Existing mushroom respiration models were described as a single process in which fruit bodies were initiated and harvested. However, it is necessary to reflect the thinning effect because the growth of fruit body changes drastically through the thinning. The objectives of this study were to quantify the $\mathrm{CO}_{2}$ emission rate of King Oyster mushrooms (Pleurotus eryngii (DC.) Quél) as a function of temperature and growth stage during the cultivation including thinning processes and validate the $\mathrm{CO}_{2}$ emission rate model.

\section{Materials and Methods}

\section{Incubation and Growth Conditions of Mushrooms}

King Oyster mushrooms (Pleurotus eryngii (DC.) Quél) cultivated in Ain-Farm (Geumgwangmyeon, Anseong, Korea) were used in this study. The disclosure strain was Sae song-ee No. 2, developed by Gyeonggi Agricultural Research Institute, Korea. The substrate used for the mushrooms consisted of a 1:1:2 mixture of sawdust:corn cob:additives with a water content of $65-68 \%$. The additives consisted of $30 \%$ wheat bran, $10 \%$ beet pulp, $6 \%$ soybean meal, and $4 \%$ dried bean curd. For their cultivation, $950 \mathrm{~mL}$ polypropylene bottles were filled with $570 \mathrm{~g}$ of substrate and sterilized for $60-90 \mathrm{~min}$ at $121^{\circ} \mathrm{C}$. Inoculated mycelium were incubated for 26-28 days and postincubated for 5 or 6 days in an incubation room maintained at a temperature of $21-22^{\circ} \mathrm{C}$ and a relative humidity of 65 $-70 \%$. After post-incubation, then the upper surface of the substrate was scraped in order to initiate the fruit bodies. After scraping, the temperature and relative humidity in the incubation room were gradually changed from 18 to $15^{\circ} \mathrm{C}$ and from 95 to $80-85 \%$, respectively.

\section{Measurement of Mycelium Occupation Ratio in Bottles with Growth Stage}

In order to analyze the growth of mycelium and fruit

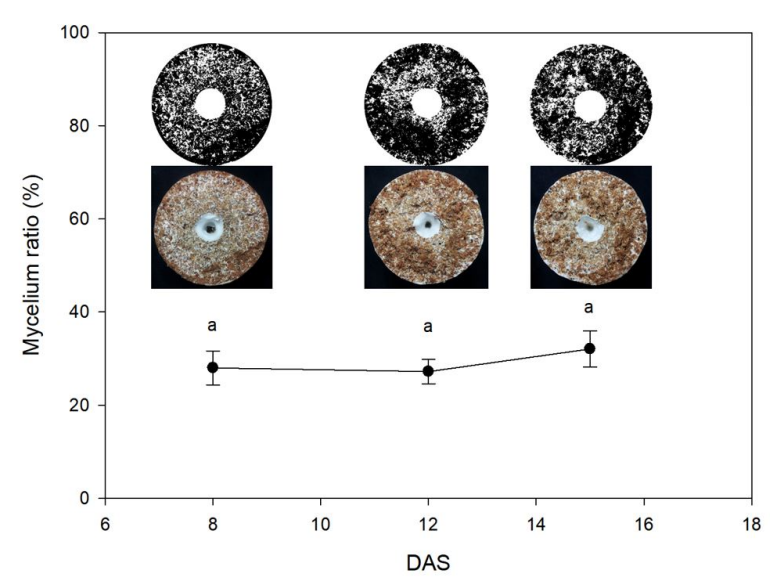

Fig. 1. Change in the mycelium proportion of King Oyster mushrooms as a function of days after scraping (DAS). Data were collected by image processing. Vertical bars represent the mean $\pm \operatorname{SD}(n=15)$. Different letters indicate a statistically significant differences (DMRT at $p<0.05$ ). Within whole growth stage, the same letters are not significantly different at 0.05 . 
bodies with days after scraping (DAS), fresh and dry weights of the substrate including mycelium were measured at 8,12 , and 15 DAS. To estimate the percentage of mycelium in the substrate, photographs of five cross-sections of cylindrical bottles (at $2 \mathrm{~cm}$ intervals) were taken in three replications. Photographs were converted to binary images using Image J (US National Institutes of Health, Bethesda, $\mathrm{MD}, \mathrm{USA}$ ), and the ratios corresponding to the percentages of substrate and mycelium were obtained by calculating the number of pixels. Among the photographs on the inside of Fig. 1, the images below were taken from the section of the substrate at each growth stage. The photographs on the top were processed using Image $\mathbf{J}$ to separate the substrate and mycelium.

\section{Measurement of $\mathrm{CO}_{2}$ Emission Rates of Substrate and Fruit Bodies}

To measure the $\mathrm{CO}_{2}$ emission rates of the substrate and fruit bodies, mushrooms were cultivated in closed acrylic chambers $(1.0 \times 0.8 \times 0.5 \mathrm{~m})$ maintained at a constant internal temperature (Fig. 2). The $\mathrm{CO}_{2}$ concentrations were measured using an infrared $\mathrm{CO}_{2}$ sensor (LI-820, LI-COR, Lincoln, NE, USA) controlled by a data logger (CR1000, Campbell Scientific, Logan, UT, USA). Mushrooms at 8, 12, and 15 DAS were used for measurement of $\mathrm{CO}_{2}$ emission rates. At $12 \mathrm{DAS}$, all but the two largest fruit bodies of 2.5 to $3 \mathrm{~cm}$ were removed (Fig. 3). Three mushroom bottles corresponding to each growth period were placed in a chamber, and the $\mathrm{CO}_{2}$ emission rate of a bottle was measured. The measurement for each bottle was repeated three times. The $\mathrm{CO}_{2}$ emission rate of mushroom bottles was calculated by measuring the $\mathrm{CO}_{2}$ concentration in the closed chamber every $5 \mathrm{~s}$. After removing fruit bodies, the $\mathrm{CO}_{2}$ emission rate of the substrate including mycelium was measured again using the same method. The $\mathrm{CO}_{2}$ emission rates of the mushrooms at 8,12 , and $15 \mathrm{DAS}$ were measured at temperatures of $16^{\circ} \mathrm{C}, 18^{\circ} \mathrm{C}, 20^{\circ} \mathrm{C}, 22^{\circ} \mathrm{C}$, and $25^{\circ} \mathrm{C}$.

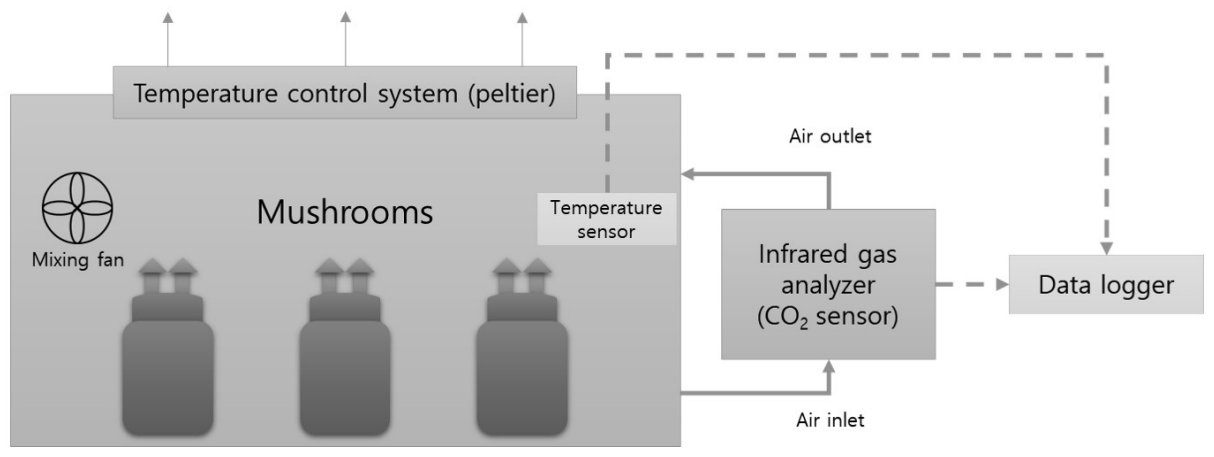

Fig. 2. Measurement of the $\mathrm{CO}_{2}$ emission rate of King Oyster mushrooms using a closed acrylic chamber $(1.0 \times 0.8 \times 0.5 \mathrm{~m})$, in which the internal temperature was controlled at temperatures of $16^{\circ} \mathrm{C}, 18^{\circ} \mathrm{C}, 20^{\circ} \mathrm{C}, 22^{\circ} \mathrm{C}$, and $25^{\circ} \mathrm{C}$. Three replicate experiments were performed simultaneously using three independent devices.

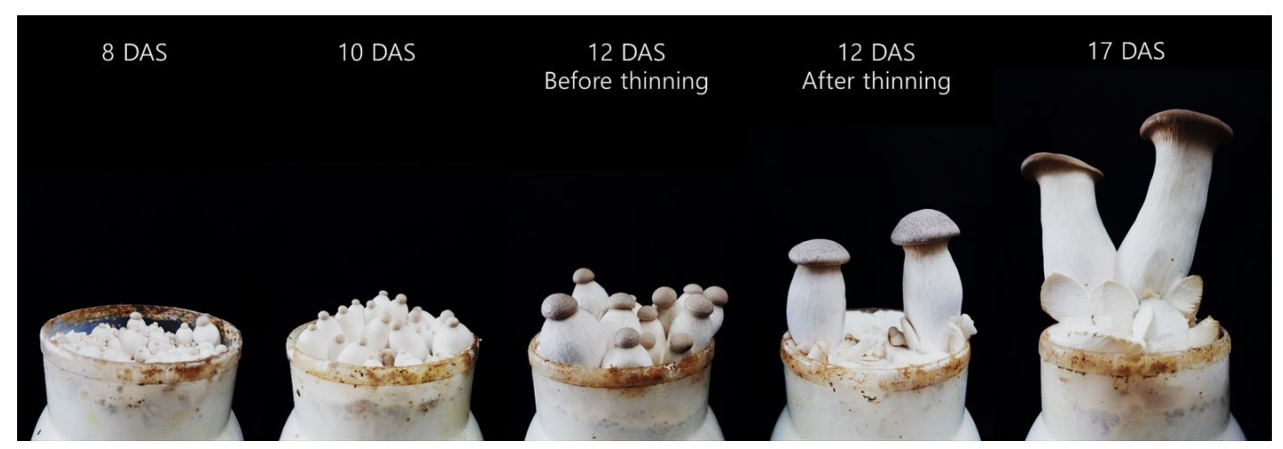

Fig. 3. Morphological changes of King Oyster mushrooms according to days after scraping (DAS). 


\section{4. $\mathrm{CO}_{2}$ Emission Models of Substrate and Fruit Bodies}

To establish a $\mathrm{CO}_{2}$ emission model of the mushrooms, the measured $\mathrm{CO}_{2}$ emission rates were regressed using the statistical program SPSS (SPSS Inc., Chicago, IL, USA). The $\mathrm{CO}_{2}$ emission rate of the substrate including mycelium as a function of temperature was expressed using Eqn. 1. The symbols used in the models are summarized in Table 1.

$$
R_{m}=a_{1} \cdot \exp \left(a_{2} \cdot T\right)+a_{3}
$$

Regression analysis was conducted at 8 DAS before thinning and at 12 and 15 DAS after thinning.

Although fruit body growth is known to follow Gompertz equation (Chanter and Thornley, 1978), the fruit bodies of King Oyster mushroom in this study were harvested before reaching the stationary phase and were thus evaluated using an exponential function (Eqn. 2). Specifically, when $k$ is assumed to be constant after thinning, it is possible to express fruit body growth as follows.

$$
W_{f}=W_{f 0} \cdot \exp (k \cdot t)
$$

Using the measured dry weights of fruit bodies at 8, 9, 11, 12,13 , and 15 DAS, regression analysis was performed with respect to time $t$.

The respiration rate of fruit bodies, divided into growth respiration and maintenance respiration, was determined by
Eqn. 3, which consists of dry weight and its rate of change (Thornley, 1970; Chanter and Thornley, 1978; Cannell and Thornley, 2000). By substituting Eqn. 2 into Eqn. 3, the following model of fruit body respiration was obtained (Eqn. 4).

$$
\begin{aligned}
& R=M \cdot W_{f}+P \cdot d W_{f} / d t \\
& R_{f}=\left(a_{4} \cdot M+a_{5} \cdot P\right) \cdot \exp \left(a_{6} \cdot t\right)
\end{aligned}
$$

Since the maintenance and $\mathrm{CO}_{2}$ production coefficients are variables related to temperature, it would be appropriate to express as quadratic forms with a maximum or minimum value using temperature. $M$ or $P$ in Eqn. 4 were defined as a function of temperature as follows:

$$
Y=a_{7} \cdot T^{2}+a_{8} \cdot T+a_{9}
$$

The respiration of fruit bodies in a mushroom bottle was obtained by the difference between $\mathrm{CO}_{2}$ emission rates before and after cutting fruit bodies.

For validation, the $\mathrm{CO}_{2}$ emission rates of the bottlecultivated mushrooms at a temperature of $24^{\circ} \mathrm{C}$ were measured in the same closed chamber at 7, 9, 11, 13, and 15 DAS. The data at 7, 9, and 11 DAS were used for the validation before thinning and those at 13 and 15 DAS after thinning.

Table 1. Parameters used in respiration models.

\begin{tabular}{cc}
\hline \hline Parameter & Description \\
\hline$a_{1} \sim a_{9}$ & Regression coefficient $($ dimensionless $)$ \\
$k$ & Relative growth rate $\left(\mathrm{g} \cdot \mathrm{g}^{-1} \cdot \mathrm{d}^{-1}\right)$ \\
$M$ & Maintenance coefficient $\left(\mathrm{s}^{-1}\right)$ \\
$P$ & $\mathrm{CO}_{2}$ production coefficient $\left[\mathrm{g} \mathrm{CO} \cdot(\mathrm{g} \mathrm{dry} \mathrm{matter})^{-1}\right]$ \\
$Y$ & ${\mathrm{Maintenance} \mathrm{or} \mathrm{CO}_{2} \text { production coefficient }(\text { dimensionless })}^{-1} \mathrm{CO}_{2}$ emission rate or respiration rate $\left(\mu \mathrm{gO}_{2} \cdot \mathrm{m}^{-2} \cdot \mathrm{s}^{-1}\right)$ \\
$R_{m}$ & $\mathrm{CO}_{2}$ emission rate of the substrate including $\mathrm{mycelium}\left(\mu \mathrm{CO}_{2} \cdot \mathrm{m}^{-2} \cdot \mathrm{s}^{-1}\right)$ \\
$R_{f}$ & $\mathrm{CO}_{2}$ emission rate of fruit bodies $\left(\mu \mathrm{g} \mathrm{CO} \mathrm{CO}^{-2} \cdot \mathrm{s}^{-1}\right)$ \\
$t$ & Days after scraping $(\mathrm{DAS}, \mathrm{d})$ \\
$T$ & Temperature $\left({ }^{\circ} \mathrm{C}\right)$ \\
$W$ & Dry weight $(\mathrm{g})$ \\
$W_{f o}$ & Initial dry weight of fruit bodies $(\mathrm{g})$ \\
\hline
\end{tabular}




\section{Statistical Analysis}

All measured data were evaluated using SPSS statistical package (IBM, New York, NY, USA). Data were analyzed with Duncan's new multiple rage test (DMRT) after an analysis of variance (ANOVA) at the significance level of 0.05 .

\section{Results}

\section{Mycelium Ratio and $\mathrm{CO}_{2}$ Emission Rate of Substrate with Growth Stage}

The mycelium ratios in the substrate were $28.01 \pm 3.64 \%$, $27.23 \pm 2.62 \%$, and $32.08 \pm 3.91 \%$ at 8,12 , and $15 \mathrm{DAS}$, respectively, and showed no significant difference among the growth stages (Fig. 1). Conversely, the $\mathrm{CO}_{2}$ emission rates of the substrate including mycelium before and after thinning were significantly different (Table 2). Using the parameters of Eqn. 1 (Table 1), the $\mathrm{CO}_{2}$ emission rates of the substrate including mycelium before and after thinning could be quantified. The value of $\mathrm{R}^{2}$ in both cases were 0.79 and 0.87 , respectively.

\section{Growth and $\mathrm{CO}_{2}$ Emission Rate of Fruit Bodies}

The dry weight of fruit bodies exponentially increased with time (Fig. 4). $W_{s 0}$ and $k$ were $0.009 \mathrm{~g}$ and 0.549 , respectively. The initial dry weight of fruit bodies after thinning was 0.002, which was obtained from Eqn. 2 using regression analysis. The reduction in initial dry weight was

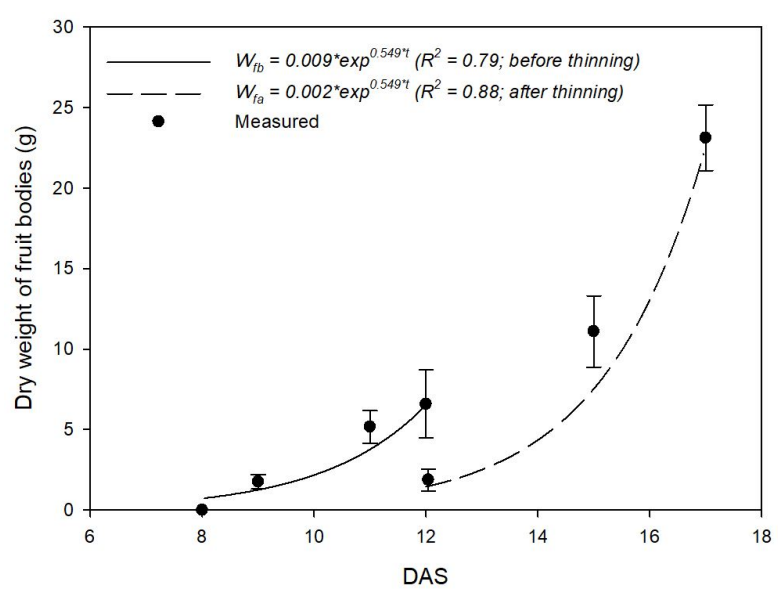

Fig. 4. Change in the dry weight of King Oyster mushroom fruit bodies at a controlled temperature of $18^{\circ} \mathrm{C}$ with days after scraping (DAS) and their regressed equations. At $12 \mathrm{DAS}$, the others of the small fruit bodies were thinned, leaving only two large fruit bodies. Vertical bars represent the mean $\pm \mathrm{SD}(n=15)$.

Table 2. $\mathrm{CO}_{2}$ emission rate $\left(\mu \mathrm{g} \mathrm{CO} 2 \cdot \mathrm{s}^{-1}\right)$ of the substrate including mycelium of King Oyster mushrooms with temperature and growth period.

\begin{tabular}{|c|c|c|c|c|c|c|}
\hline \multirow{2}{*}{$\begin{array}{l}\text { Growth stage } \\
\left(\mathrm{DAS}^{\mathrm{z}}\right)\end{array}$} & \multicolumn{5}{|c|}{ Temperature $\left({ }^{\circ} \mathrm{C}\right)$} & \multirow{2}{*}{$\mathrm{R}^{2}$} \\
\hline & 16 & 18 & 20 & 22 & 25 & \\
\hline \multicolumn{7}{|c|}{ Before thinning } \\
\hline 8 & $40.24 \pm 6.08^{y} a$ & $40.13 \pm 1.14 \mathrm{a}$ & $49.61 \pm 3.05 \mathrm{a}$ & $54.43 \pm 4.31 \mathrm{a}$ & $59.78 \pm 4.20 \mathrm{a}$ & 0.80 \\
\hline \multicolumn{7}{|c|}{ After thinning } \\
\hline 12 & $61.36 \pm 10.49 b$ & $68.43 \pm 4.88 b$ & $77.54 \pm 5.63 \mathrm{~b}$ & $90.28 \pm 7.08 \mathrm{~b}$ & $115.42 \pm 10.08 b$ & 0.87 \\
\hline 15 & $52.39 \pm 3.54 \mathrm{ab}$ & $76.25 \pm 7.54 b$ & $83.48 \pm 4.00 \mathrm{~b}$ & $98.69 \pm 8.74 b$ & $112.45 \pm 11.91 b$ & 0.87 \\
\hline
\end{tabular}

*Different letters indicate a statistically significant differences (DMRT at $p<0.05$ ).

${ }^{\mathrm{z}} \mathrm{DAS}$, days after scraping.

${ }^{\mathrm{y}} \operatorname{Mean} \pm \operatorname{SD}(n=3)$.

Table 3. Regression parameters of $\mathrm{CO}_{2}$ emission rate models of the substrate including mycelium $\left(R_{m}\right.$, Eqn. 1$)$ and the fruit bodies of King Oyster mushrooms $\left(R_{f}\right.$, Eqn. 5$)$ before and after thinning processes.

\begin{tabular}{|c|c|c|c|c|c|c|c|c|}
\hline \multirow{2}{*}{ Growth stage } & \multicolumn{4}{|c|}{$R_{m}^{\mathrm{z}}$} & \multicolumn{4}{|c|}{$R_{f}$} \\
\hline & $a_{1}$ & $a_{2}$ & $a_{3}$ & $\mathrm{R}^{2}$ & $a_{4}$ & $a_{5}$ & $a_{6}$ & $\mathrm{R}^{2}$ \\
\hline Before thinning & 143.370 & 0.013 & -137.343 & 0.79 & 0.009 & 0.00494 & 0.549 & 0.79 \\
\hline After thinning & 260.417 & 0.017 & -282.851 & 0.87 & 0.012 & 0.00110 & 0.549 & 0.88 \\
\hline
\end{tabular}

${ }^{\mathrm{z}}$ Refer to Table 1 for $R_{m}$ and $R_{f}$. 


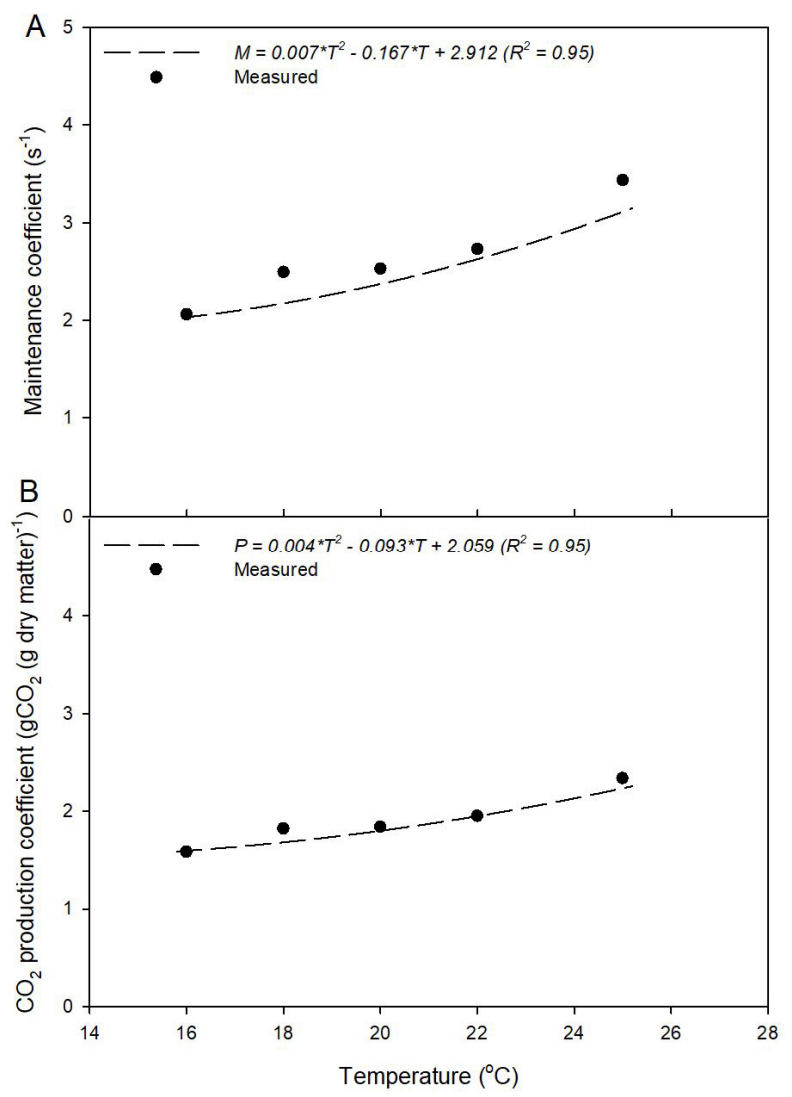

Fig. 5. Changes in the maintenance (A) and $\mathrm{CO}_{2}$ production (B) coefficients as a function of temperature.

induced by thinning process. The values of $\mathrm{R}^{2}$ in the two cases were estimated as 0.79 and 0.88 , respectively. The $\mathrm{CO}_{2}$ emission rates of fruit bodies before and after thinning could be quantified by using the parameters of Eqn. 5 described in Table 3. The values of $M$ and $P$ were expressed as quadratic equations and increased with increase of temperature (Fig. 5).

\section{Total $\mathrm{CO}_{2}$ Emission Rate of One Bottle of King Oyster} Mushroom

The $\mathrm{CO}_{2}$ emission rate with growth stage and temperature for mushroom cultivation bottle was described (Fig. 6) by applying the $\mathrm{CO}_{2}$ emission rate models of the substrate including mycelium and the fruit bodies before and after thinning (Table 3). The total $\mathrm{CO}_{2}$ emission rate of mushroom cultivation bottles exponentially and linearly with growth stage and temperature, respectively. In validation, the $\mathrm{CO}_{2}$ emission rates estimated by the models were in a good

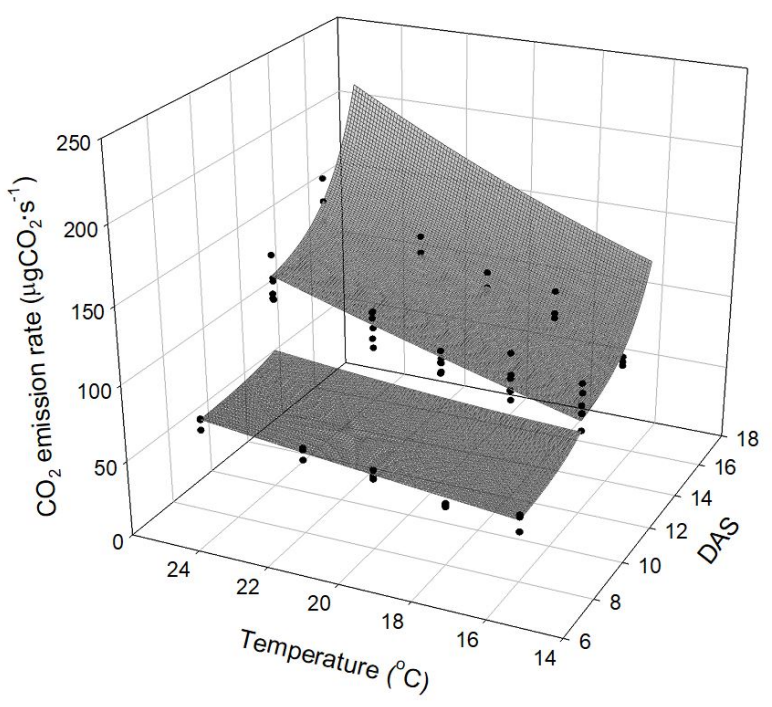

Fig. 6. $\mathrm{CO}_{2}$ emission rates of King Oyster mushrooms in cultivation bottles according to temperature and days after scraping (DAS). Left and right planes mean regressed $\mathrm{CO}_{2}$ emission rates before and after thinning, respectively.

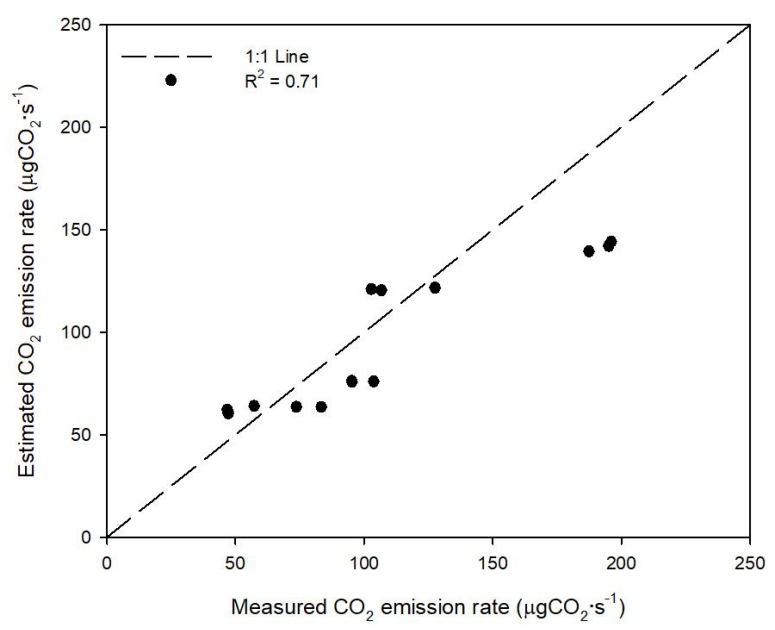

Fig. 7. Validation of the measured and estimated $\mathrm{CO}_{2}$ emission rates of King Oyster mushrooms in cultivation bottles at a controlled temperature of $25^{\circ} \mathrm{C}$.

agreement with those measured at a temperature of $24^{\circ} \mathrm{C}$ (Fig. 7). Before the thinning stage, the $\mathrm{CO}_{2}$ emission rate estimated by the model was close to $60 \mu \mathrm{g} \mathrm{CO}_{2} \cdot \mathrm{s}^{-1}$, while actual values ranged from 40 to $110 \mu \mathrm{g} \mathrm{CO}_{2} \cdot \mathrm{s}^{-1}$. After the thinning stage, the estimated values ranged from 130 to 150 $\mu \mathrm{g} \mathrm{CO}{ }_{2} \cdot \mathrm{s}^{-1}$, but the actual values were between 100 and 200 $\mu \mathrm{g} \mathrm{CO}{ }_{2} \cdot \mathrm{s}^{-1}$. The value of $\mathrm{R}^{2}$ in validation was approximately 0.71 . 


\section{Discussion}

Mycelial growth in a limited volume of growth media can be represented by logistic curves that are dependent on the carrying capacity of $\mathrm{K}^{+}$(Koch, 1975). In a previous study, cross-sectional images of the substrate consisting of growth media and mycelia were used to identify a stationary phase in which the ratio of mycelia to the substrate was constant. The presence of this stationary phase suggested that the mycelia of the mushrooms used in this study were in the latter part of the logistic growth phase. This observation is consistent with a previous research showing that mycelia enter into a stationary phase after six days of incubation (Yang et al., 2010). On the other hand, the mycelial dry weights of Flammulina velutipes was decreased after fruit body initiation (Kitamoto and Gruen, 1976). There are two possible explanations for this observation. First, the nutrients in the medium may be reduced at the onset of the stationary phase as a result of mycelia feeding. Secondly, the nutrients may move to fruit bodies from the mycelia to facilitate fruit body growth (Chanter and Thornley, 1978). Indeed, the presence of an abundance of nutrients in the waste media of mushroom cultivation by-products has led to the use of such waste media as fodder in other applications (Kim et al., 2010). However, under the experimental conditions of this study, the ratio of mycelium in the substrate was not decreased. This result indicates that the mycelial growth stage reaches the stationary phase, meaning that mycelium no longer grew but only fruit body did.

In a previous study based on image processing methods, the proportion of mycelium was determined to be greater than $60 \%$ during the entire growth period (Yang et al., 2010 ), while the present study identified a ratio of $30 \%$. This difference may be due to the specific media used in the two studies: wood and corncob chips were used in the previous study, while the present study utilized sawdust. The difference in color between the media might have also affected our estimation. Therefore, it is necessary to provide a reference for estimating the proportion of mycelium when using image-based measurements. And soil respiration measurement systems can be used to measure the rate of $\mathrm{CO}_{2}$ emission of mycelium in a given substrate (Bekku et al., 1995). Alternatively, respiration rates can be measured within a relatively short time by connecting the infra-red gas analyzer and the chamber (Rochette et al., 1997; Takahashi et al., 2008; Brändle and Kunert, 2019).

During the thinning process, the base parts of medium and fruit body suffer physical damage. Following these wounds, the mushroom respiration rate increases, and plant tissues age (Fonseca et al., 2002). Because the respiration of harvested mushrooms is closely related to their quality, this phenomenon has been quantified (Jacxsens et al., 2001; Pogorzelska-Nowicka et al., 2020). In this study, although there was no significant change in proportion of the mycelium, the $\mathrm{CO}_{2}$ emission rate of mycelium changed significantly (Table 2). However, because cutting a large number of small fruit bodies before thinning caused physical damages, $\mathrm{CO}_{2}$ emission rates of fruit bodies at this stage were overestimated, resulting in a negative relationship between the values of $M$ and $P$ and the temperature. Therefore, the values of $M$ and $P$ obtained after thinning were used in the model. Based on this result, we inferred that the $\mathrm{CO}_{2}$ emission rate increased due to thinning rather than mycelium growth. In cases of Agaricus bisporus and Pleurotus eryngii, the respiration rates of fruit bodies after harvest were $97.02 \pm 2.51$ at $20^{\circ} \mathrm{C}$ (Iqbal et al., 2009) and $300 \mathrm{~mL} \cdot \mathrm{kg}^{-1} \cdot \mathrm{h}^{-1}$ at $18^{\circ} \mathrm{C}$ (Azevedo et al., 2015), respectively. In this study, the respiration rate of the mushroom during cultivation was about $22,370 \mathrm{~mL} \cdot \mathrm{kg}^{-1}$. $\mathrm{h}^{-1}$ at $20^{\circ} \mathrm{C}$. There was no study to measure the respiration rate of cultivated mushroom to date, it was inevitable to compare it with the measurement of respiration rate for mushroom after harvest. However, it was possible to predict the $\mathrm{CO}_{2}$ emitted in the substrate and fruit bodies of the mushroom by the respiration model previously developed (Chanter and Thornley, 1978), so that the regression coefficient can be obtained by using the existing respiration model in mushroom cultivation.

Yang et al. (2012) developed a model for the growth of mycelium or fruit bodies of King Oyster mushroom, but the respiration rate model was not associated. In this study, we developed a growth-respiration combined model for the substrate including mycelium and the fruit bodies with regressed $R^{2}$ values of 0.79 to 0.88 . The $R^{2}$ value of 0.71 was considered a little lower in the validation due to the measurement of three points near $200 \mu \mathrm{g} \mathrm{CO} 2 \cdot \mathrm{s}^{-1}$ (Fig. 7). These results appeared because the growth model estimated 
the dry weight of fruit bodies below the actual value at 15 DAS (Fig. 4). Thus more sophisticated methods for estimating $\mathrm{CO}_{2}$ emissions from substrate and fruit bodies are required. Utilizing $\mathrm{CO}_{2}$ emission rate models established in this study, the increase in $\mathrm{CO}_{2}$ concentration in mushroom cultivation facilities can be estimated and an efficient ventilation strategy will be established. For practical points of view, utilization of $\mathrm{CO}_{2}$ emitted during mushroom cultivation can be used for plant photosynthesis (Kitaya et al., 1994; Tani et al., 1996; Jung et al., 2014).

In this study, we found that the $\mathrm{CO}_{2}$ emission rates of the mushroom exponentially and linearly increased with growth stage and temperature, respectively, and clarified that the $\mathrm{CO}_{2}$ emission rate drastically increased after thinning processes. The $\mathrm{CO}_{2}$ emission rate models developed in this study can be used to control $\mathrm{CO}_{2}$ concentration for adequate mushroom cultivation.

\section{Literature Cited}

Azevedo S., L.M. Cunha, and S.C. Fonseca 2015, Modelling the influence of time and temperature on the respiration rate of fresh oyster mushrooms. Food Sci. Technol. Int 21:593-603. doi:10.1177/1082013214555925

Bekku Y., H. Koizumi, T. Nakadai, and H. Iwaki 1995, Measurement of soil respiration using closed chamber method: an IRGA technique. Ecol. Res 10:369-373. doi: $10.1007 /$ bf02347863

Brändle J., and N. Kunert 2019, A new automated stem $\mathrm{CO}_{2}$ efflux chamber based on industrial ultra-low-cost sensors. Tree Physiol 39:1975-1983. doi:10.1093/treephys/tpz104

Burton K.S., and R. Noble 1993, The influence of flush number, bruising and storage temperature on mushroom quality. Postharvest Biol. Technol 3:39-47. doi:10.1016/ 0925-5214(93)90025-x

Cannell M.G.R., and J.H.M. Thornley 2000, Modelling the components of plant respiration: some guiding principles. Ann. Bot 85:45-54. doi:10.1006/anbo.1999.0996

Chanter D.O., and J.H.M. Thornley 1978, Mycelial growth and the initiation and growth of sporophores in the mushroom crop: a mathematical model. J. Gen. Microbiol 106:55-65. doi:10.1099/00221287-106-1-55

Flegg P.B., and J.F. Smith 1982, Effect of spawn strain and available substrate on the relative yield of mushrooms in successive flushes. Sci. Hortic 17:217-222. doi:10.1016/ 0304-4238(82)90043-7

Fonseca S.C., F.A.R. Oliveira, and J.K. Brecht 2002, Modelling respiration rate of fresh fruits and vegetables for modified atmosphere packages: a review. J. Food Eng 52:99-119. doi:10.1016/s0260-8774(01)00106-6

Iqbal T., F.A.S. Rodrigues, P.V. Mahajan, and J.P. Kerry 2009, Mathematical modelling of $\mathrm{O}_{2}$ consumption and $\mathrm{CO}_{2}$ production rates of whole mushrooms accounting for the effect of temperature and gas composition. Int. J. Food Sci. Technol 44:1408-1414. doi:10.1111/j.1365-2621.2009.01971.x

Jacxsens L., F. Devlieghere, C. van der Steen, and J. Debevere 2001, Effect of high oxygen modified atmosphere packaging on microbial growth and sensorial qualities of fresh-cut produce. Int. J. Food Microbiol 71:197-210. doi:10.1016/ s0168-1605(01)00616-x

Jang M.J., T.M. Ha, and Y.C. Ju 2007, Comparison of respiration characteristics on the new variety of oyster mushroom according to the growth temperature. J. Mushroom Sci. Product 5:65-70.

Jang M.J., T.M. Ha, Y.H. Lee, and Y.C. Ju 2009, Growth characteristics of variety of oyster mushroom (Pleurotus ostreatus) as affected by number of air exchanges. J. Bio-Environ. Cont 18:208-214.

Jung D.H., C.K. Kim, K.H. Oh, D.H. Lee, M.S. Kim, J.H. Shin, and J.E. Son 2014, Analyses of $\mathrm{CO}_{2}$ concentration and balance in a closed production system for King Oyster mushroom and lettuce. Hortic. Sci. Technol 10:628-635. doi:10.7235/hort.2014.13192

Kamal A.S.M., A. Khair, F. Begum, K. Chowdhury, and R. Karim 2015, Effect of respiratory gases $\left(\mathrm{O}_{2} ; \mathrm{CO}_{2}\right)$ on shelf-life of fresh oyster mushrooms packaged with different sealable polymeric materials. Bangladesh J. Sci. Ind. Res 50:205-210. doi:10.3329/bjsir.v50i3.25587

Kües U., and Y. Liu 2000, Fruiting body production in basidiomycetes. Appl. Microbiol. Biotechnol 54:141-152. doi:10.1007/s002530000396

Kim K.J., D.M. Kim, H.S. An, J.K. Choi, and S.G. Kim 2019, Analysis of the growth environment and fruiting body quality of Pleurotus eryngii cultivated by smart farming. J. Mushrooms 17:211-217.

Kim Y.I., J.S. Seok, and W.S. Kwak 2010, Evaluation of microvially ensiled spent mushroom (Pleurotus osteratus) substrate (bed-type cultivation) as a roughage for ruminants. J. Anim. Sci. Technol 52:117-124. doi:10.5187/jast.2010. 52.2.117

Kinugawa K., A. Suzuki, Y. Takamatsu, M. Kato, and K. Tanaka 1994, Effects of concentrated carbon dioxide on the fruiting of several cultivated basidiomycetes (II). Mycoscience 35:345-352. doi:10.1007/bf02268504

Kitamoto Y., and H.E. Gruen 1976, Distribution of cellular carbohydrates during development of the mycelium and fruitbodies of Flammulina velutipes. Plant Physiol 58:485491. doi:10.1104/pp.58.4.485

Kitaya Y., A. Tani, M. Kiyota, and I. Aiga 1994, Plant growth 
Dae Ho Jung and Jung Eek Son

and gas balance in a plant and mushroom cultivation system. Adv. Space Res 14:281-284. doi:10.1016/0273-1177(94) 90309-3

Koch A.L. 1975, The kinetics of mycelial growth. J. Gen. Microbiol 89:209-216. doi:10.1099/00221287-89-2-209

Lee D.J., K.P. Kim, and B.E. Lee 2003, Studies on artificial cultivation of Pleurotus eryngii (De Canolle ex Freies) Quel. Kor. J. Mycol 31:192-199. doi:10.4489/kjm.2003.31.3.192

Oh T.S., Y.H. Lee, C.H. Kim, Y.K. Cho, and M.J. Jang 2017, Comparative study of the growth characteristics of Pleurotus eryngii by using alternative substrates to rice bran. J. Mushrooms 15:57-60. doi:0.14480/jm.2017.15.1.57

Pogorzelska-Nowicka E., M. Hanula, I. Wojtasik-Kalinowska, A. Stelmasiak, M. Zalewska, A. Półtorak, and A. Wierzbicka 2020, Packaging in a high $\mathrm{O}_{2}$ or air atmospheres and in microperforated films effects on quality of button mushrooms stored at room temperature. Agriculture 10:479. doi:10.3390/ agriculture 10100479

Rochette P., B. Ellert, E.G. Gregorich, R.L. Desjardins, E. Pattey, R. Lessard, and B.G. Johnson 1997, Description of a dynamic closed chamber for measuring soil respiration and its comparison with other techniques. Can. J. Soil Sci 77:195-203. doi:10.4141/s96-110

Ryu J.S., M.K. Kim, S.H. Cho, Y.C. Yun, W.M. Seo, and H.S. Lee 2005, Optimal $\mathrm{CO}_{2}$ level for cultivation of Pleurotus eryngii. J. Mushroom Sci. Product 3:95-99.

Takahashi N., P.P. Ling, and J.M. Frantz 2008, Considerations for accurate whole plant photosynthesis measurement. Environ. Cont. Biol 46:91-101. doi:10.2525/ecb.46.91

Tani A., M. Kiyota, I. Aiga, K. Nitta, Y. Tako, A. Ashida, K. Otsubo, and T. Saito 1996, Measurements of trace contaminants in closed-type plant cultivation chambers. Adv. Space Res 18:181-188. doi:10.1016/0273-1177(95) 00875-f

Thornley J.H.M. 1970, Respiration, growth and maintenance in plants. Nature 227:304-305. doi:10.1038/227304b0

Yamanaka K. 2011, Mushroom cultivation in Japan. The World Society for Mushroom Biology and Mushroom Products (WSMBMP) Bulletin 4:1-10.

Yang J., J.Y. Zhao, Q. Guo, Y.S. Wang, and R.J. Wang 2010, Data acquisition method for measuring mycelium growth of microorganism with GIS. In International Conference on Computer and Computing Technologies in Agriculture, Springer, Berlin, Heidelberg, pp. 374-380. doi:10.1007/978 -3-642-18333-1_44

Yang J., J.Y. Zhao, H. Yu, L.H. Tang, and R.J. Wang 2012, Mathematical study of the effects of temperature and humidity on the mycelium growth of Pleurotus eryngii. In Agro-Geoinformatics, 2012 First International Conference on, Institute of Electrical and Electronics Engineers, New York, pp 1-5. doi:10.1109/agro-geoinformatics.2012.6311639

Zadražil F. 1975, Influence of $\mathrm{CO}_{2}$ concentration on the mycelium growth of three Pleurotus species. Eur. J. Appl. Microbiol. Biotechnol 1:327-335. doi:10.1007/bf01382692

\title{
생육 시기와 온도에 따른 속아내기 전후의 새송이버섯의 이산화탄소 발생 속도 모델링 \\ 정대호 ${ }^{1} \cdot$ 손정익 ${ }^{2,3 *}$ \\ ${ }^{1}$ 제주한라대학교 생명자원학부 환경원예과 조교수, ${ }^{2}$ 서울대학교 농림생물자원학부 교수, \\ ${ }^{3}$ 서울대학교 농업생명과학연구원 겸임연구원
}

\begin{abstract}
적 요. 온도와 $\mathrm{CO}_{2}$ 농도는 버섯의 생육과 품질에 영향을 미친다. 특히, 버섯의 호흡에 의한 고농도 $\mathrm{CO}_{2}$ 는 버섯의 생리 장해를 발생시킨다. 본 연구에서는 생육 시기와 솎아내기 여부에 따른 새송이 버섯(Pleurotus eryngii (DC.) Quél)의 $\mathrm{CO}_{2}$ 발생 속도를 정량화 하였다. 버섯의 자실체를 포함하는 배지의 $\mathrm{CO}_{2}$ 발생 속도는 솎아내기 전에 비해 후에 통계적으로 유의미한 상승을 보였다. 호흡 모델에서 자실체의 유지 계수와 $\mathrm{CO}_{2}$ 발생 계수는 온도에 따른 이차 식으로 표현되었다. 버섯 1 병의 $\mathrm{CO}_{2}$ 발생 속도 모델에 의한 추정치는 실측치와 검증을 통해 $\mathrm{R}^{2}=0.71$ 의 결과를 나 타내었다. 이로부터 버섯의 $\mathrm{CO}_{2}$ 발생 속도는 생육 시기에 따라 지수적으로, $16^{\circ} \mathrm{C}$ 에서 $25^{\circ} \mathrm{C}$ 범위에서 이차함수 형 태로 증가함을 확인하였다. 본 연구에서 정립한 새송이 버섯의 $\mathrm{CO}_{2}$ 발생 속도 모델은 새송이버섯을 재배사의 $\mathrm{CO}_{2}$ 와 온도 관리를 위해 사용될 수 있다.
\end{abstract}

추가 주제어: 균사, 배지, 이산화탄소, 자실체, 호흡 모델 